\title{
Cellular Localization of Rheumatoid Factor Idiotypes
}

\author{
Vincent R. Bonagura, Henry G. Kunkel, and Benvenuto Pernis, Department \\ of Microbiology, College of Physicians \& Surgeons, Comprehensive Cancer \\ Center, Columbia University, New York 10032; The Rockefeller University, \\ New York 10021
}

A B S TRACT The stimulation of lymphocytes from rheumatoid arthritis patients with pokeweed mitogen produces a large number of plasma cells that express the dominant cross-reactive idiotype previously found on monoclonal IgM anti-gamma-globulins from patients with mixed cryoglobulinemia. Similar experiments with the cells of normal individuals show a much lower percentage of these cells with a lower intensity of staining with the fluorescent reagents utilized. Efforts to demonstrate rheumatoid factor in the same cells by fluorescent staining with aggregated gammaglobulin were entirely unsuccessful. This also proved to be the case for pokeweed mitogen-stimulated cells from the mixed cryoglobulinemic patients with large amounts of rheumatoid factor in the serum, despite high percentages of cells expressing the cross-reactive idiotype and also the individual idiotype. On the other hand, native plasma cells from synovial tissue of rheumatoid arthritis patients showed some cells with both the cross-reactive idiotype and aggregate staining. The exact reason for the failure to demonstrate rheumatoid factor by aggregate staining in pokeweed mitogenstimulated cultures remains to be determined despite considerable effort to resolve the problem. The most likely possibility is that these plasma cells are relatively immature and have not accumulated polymeric IgM in their cytoplasm to the degree seen in synovial tissue plasma cells. The monomeric forms are readily recognized by the antiidiotypic antibodies and these reagents appear to be of particular value for cellular studies of this type.

\section{INTRODUCTION}

Monoclonal rheumatoid factors of the IgM type are found primarily in the blood of a proportion of patients

This work was presented in part at the Arthritis and Rheumatism Association National Meeting in Atlanta, GA, 30 May 1980.

Address reprint requests to Dr. Benvenuto Pernis at Columbia University.

Received for publication 19 October 1981 and in revised form 9 February 1982. with cryoglobulinemia. In their sera a monoclonal IgM component reacts, in the cold, with the polyclonal IgG giving a precipitate containing a mixture of $\operatorname{IgM}$ and IgG (1). An antigenic analysis of the monoclonal IgM from different patients (2) has shown that they have cross-reacting idiotypes. On the basis of idiotype crossreactivity the rheumatoid factor cryoglobulins can be classified in a major group (Wa) that includes close to $60 \%$ of the patients, and a number of minor groups.

The impression has been widespread that the polyclonal rheumatoid factors, such as those that are in the blood of $60-80 \%$ of patients with active rheumatoid arthritis, are different from the monoclonal IgM anti-IgG immunoglobulins of the mixed cryoglobulinemias because their reaction with IgG has different $\mathrm{pH}$ and temperature requirements. The majority of patients with rheumatoid arthritis show little or no cryoglobulin.

On the other hand, recently Forre et al. (3) have published evidence that supports the existence of crossreacting idiotypes common to monoclonal and polyclonal rheumatoid factors. Our work has shown that plasma cells containing immunoglobulins that react with antibodies specific for the cross-reacting idiotypic determinants of the monoclonal rheumatoid factors of sub-group $\mathrm{Wa}$ are numerous in the synovial tissues of patients with rheumatoid arthritis. Furthermore, a relatively high percentage of cells that contain immunoglobulins that react with the same antibodies can be induced in vitro by cultivation of the peripheral blood lymphocytes from patients with active rheumatoid arthritis with pokeweed mitogen (PWM). ${ }^{1}$ These cells were similar to those seen in PWM cultures of the lymphocytes from the blood of patients with cryoglobulinemia of the Wa group, although not as numerous.

\footnotetext{
${ }^{1}$ Abbreviations used in this paper: CRI, cross-reactive idiotype; FCS, fetal calf serum; NHS, normal human serum; PBL, peripheral blood lymphocytes; PBS, phosphate-buffered saline; PWM, pokeweed mitogen; RA, rheumatoid arthritis; RF, rheumatoid factor.
} 
It appears, therefore, that B cell clones idiotypically related to those of the monoclonal rheumatoid factors are numerous in the joint lesions of rheumatoid arthritis and also in the blood of patients with an active form of the disease. In this respect the human rheumatoid factor system appears to be characterized by cross-reacting idiotypes (CRI) that are found in different monoclonal immunoglobulins as well as in apparently polyclonal products. The major human rheumatoid factor CRI (RCRI) is, in this respect, similar to the CRI that are prominent in different mouse antibody systems such as the anti-dextran system (4), the anti-arsonate (Ars) system (5), and one antiallotype system (6).

\section{METHODS}

Human cells. Eight active rheumatoid arthritis patients with high titer human IgG latex particle agglutination were studied for the production of CRI in pokeweed mitogen cultures. Two rheumatoid patients underwent synovectomies and cells from these synovia were also studied for the presence of CRI by indirect immunofluorescence. The synovial cell suspensions from these two patients as well as the peripheral blood of one of them were obtained through the courtesy of Dr. R. Winchester, Hospital for Joint Diseases, New York. The serological data of the rheumatoid arthritis patients as well as those of the five normal volunteers used as controls are given in Table I.

In addition, the cells from two patients with cryoglobulinemia of the mixed type of the Wa group were studied. One of these patients (Glo) has been the subject of previous studies (7); the other patient (M.C.) was available through the courtesy of Dr. J. Lindenbaum, Columbia University, New York; the monoclonal IgM protein of this second patient

TABLE I

Summary of the Subjects

\begin{tabular}{llrrr}
\hline \multicolumn{1}{c}{ RA } & Gender & Age & $\begin{array}{c}\text { Latex titer } \\
\times 10^{-1}\end{array}$ & $\begin{array}{r}\text { Waaler Rose } \\
\text { titer } \times 10^{-1}\end{array}$ \\
\hline E.F. & F & 58 & 4,000 & 256 \\
M.S. & F & 54 & 16,000 & 8 \\
E.C. & F & 74 & 16,000 & 16 \\
M.J. & F & 65 & 16,000 & 32 \\
J.J. & F & 50 & 32,000 & 512 \\
J.S. & F & 45 & 16,000 & 16 \\
H.L. & M & 48 & 16,000 & N.D. \\
B.B. & F & 52 & 8,000 & N.D.
\end{tabular}

\section{Controls}

\begin{tabular}{lllll} 
N.A. & M & 23 & Negative & 8 \\
V.B. & M & 31 & Negative & 4 \\
D.E. & F & 54 & Negative & 4 \\
L.K. & F & 40 & Negative & 4 \\
P.R. & M & 25 & Negative & 4 \\
\hline
\end{tabular}

- Not determined. was assigned to the Wa group by hemagglutination inhibition.

Production of antibodies against the RCRI. Purified monoclonal IgM kappa proteins from patients $\mathrm{Wa}$ and $\mathrm{Ea}$ (members of the CRI group as described previously [2]) were separately injected into two and three Flanders Giant rabbits, respectively, $3 \mathrm{~kg}$ each, in complete Freund's adjuvant; the rabbits were then boosted with antigen in incomplete Freund's adjuvant at 4 and 6 wk after the primary immunization. Serial bleedings were performed and sera were tested for the production of anti-RCRI antibodies by hemagglutination.

Screening of antisera for anti-RCRI antibodies by hemagglutination. Sheep erythrocytes (Colorado Serum, Denver, $\mathrm{CO}$ ) were washed three times in $0.9 \%$ saline and aliquots were coupled with monoclonal IgM proteins $\mathrm{Wa}$, Ea (rheumatoid factor positive), Ter, Bro, Low (rheumatoid negative) with chromium chloride as previously described (8).

$1-\mathrm{cm}^{3}$ aliquots of antisera from the five immunized rabbits were absorbed in solid or fluid phase with $2 \mathrm{mg}$ of monoclonal IgM, rheumatoid negative, and $6 \mathrm{mg}$ of a $50 \%$ ammonium sulfate precipitate of normal human serum for 24 $\mathrm{h}$ at $4^{\circ} \mathrm{C}$. Aliquots were then spun at $10,000 \mathrm{rpm}$ for $30 \mathrm{~min}$ to precipitate gross aggregates and then ultracentrifuged for $24 \mathrm{~min}$ at $181,000 \mathrm{~g}$ to sediment $21 \mathrm{~S}$ complexes.

Unabsorbed, solid, and fluid phase-absorbed aliquots of antisera were titrated in hemagglutination against the various monoclonal IgM coats.

Preparation of RCRI antibodies for indirect immunofluorescence. Aliquots of rabbit antisera, shown by the previously described procedure to be rich in antibodies directed against the RCRI were pooled, heat inactivated, and absorbed with packed sheep erythrocytes and human erythrocytes before solid-phase affinity chromatography.

In short, anti-RCRI antibodies made of purified Ea IgM protein were absorbed on solid-phase (Sepharose coupled) immunoabsorbents including cord sera, pooled polyclonal IgG, and four monoclonal IgM-kappa rheumatoid-negative immunoglobulins. Nonadherent antibodies were then absorbed on a Sepharose-coupled column of purified Wa IgM protein. Affinity purified antibodies were then eluted with $0.1 \mathrm{~N} \mathrm{HCl}$ and the eluate was immediately neutralized with $1 \mathrm{M}$ Tris- $\mathrm{HCl}$ or eluted with $0.05 \mathrm{M}$ glycine $\mathrm{HCl}, \mathrm{pH} \mathrm{2.8}$, neutralized, and then dialyzed into $0.01 \mathrm{M}$ phosphate-buffered saline (PBS) at $4^{\circ} \mathrm{C}$. Further absorption was done in the fluid phase ( $30 \mathrm{~min}$ on ice) with increasing concentrations of pooled normal human serum from 3 to $50 \%$. The resulting antibodies were used in indirect immunofluorescence to identify RCRI antibody positive plasma cells in PWM cultures and synovial cell preparations. One preparation of antiRCRI antibodies was prepared without the addition of fluid pooled normal serum, but instead the final absorption was performed on a solid-phase (Sepharose coupled) polyclonal normal IgM column.

Preparation of affinity purified antibodies to human $F\left(a b^{\prime}\right)_{2} \mu m$ and rabbit IgG. Goat antisera to human IgM was absorbed over a Sepharose-coupled purified human IgG column and antibodies that were eluted from the column with $0.05 \mathrm{M}$ glycine $\mathrm{HCl}, \mathrm{pH} 2.8$, were concentrated and tested in Ouchterlony gel to demonstrate reactivity with IgG, IgM, IgD, and IgA. These antibodies were coupled with tetraethyl rhodamine isothiocyanate as previously described (9). Resulting antibodies were used to stain plasma cells directly in immunofluorescence. Goat antibodies that did not adhere to the IgG column were tested for reactivity with IgG, IgM, and IgA in hemagglutination and were absorbed 
on a human Sepharose-coupled IgM column. Glycine $\mathrm{HCl}$ $0.05 \mathrm{M}, \mathrm{pH} 2.8$, eluted antibodies, after neutralization, were coupled with tetraethyl rhodamine isothiocyanate as before. Specificity for IgM was tested by immunofluorescence staining of a panel of human monoclonal plasma cells.

Tetraethyl rhodamine isothiocyanate and fluorescein isothiocyanate coupled rabbit anti-human kappa and lambda were commercially prepared (Meloy Laboratories, Springfield, VA) and used directly in immunofluorescence at 0.5 $\mu \mathrm{g} / \mathrm{ml}, 20 \mu \mathrm{l} / \mathrm{slide}$. Affinity purified antibodies were used at $150-200 \mu \mathrm{g} / \mathrm{ml}, 20 \mu \mathrm{l} / \mathrm{slide}$.

A sheep antiserum made to rabbit IgG was absorbed on a column of purified rabbit IgG. Glycine $\mathrm{HCl} 0.05 \mathrm{M}, \mathrm{pH}$ 2.8 , eluted antibodies were conjugated with fluorescein as described and used at $200 \mu \mathrm{g} / \mathrm{ml}, 20 \mu \mathrm{l} /$ slide. All anti-human immunoglobulin antisera were absorbed with solid rabbit immunoglobulins before use in double staining

Preparation of PWM-induced plasma cells from rheumatoid patients and normal blood lymphocytes. $15 \mathrm{ml}$ of peripheral blood were heparinized and placed on Ficollhy paque density gradients to separate peripheral blood mononuclear cells. These cells were washed twice with PBS, 0.01 $\mathrm{M}, \mathrm{pH} 7.2,10 \%$ fetal calf serum (FCS) at $200 \mathrm{~g}$ for $10 \mathrm{~min}$ at $4^{\circ} \mathrm{C}$. After washing, the mononuclear cells were incubated on plastic dishes $30 \mathrm{~min}$ at $37^{\circ} \mathrm{C}$ in $5 \% \mathrm{CO}_{2}$ in air to partially macrophage-deplete them before placing in culture. Nonadherent cells were adjusted to $1 \times 10^{6} / \mathrm{ml}$ in RPMI 1640 plus 20\% FCS and plated as 4-ml aliquots in 12-well Linbro tissue culture plates, with $160 \mu \mathrm{l} / 4 \mathrm{~cm}^{3}$, PWM (Gibco Laboratories, Grand Island Biological Co., Grand Island, NY) reconstituted with sterile water. Cultures were harvested on day 5 and cells were washed twice with $\mathrm{PBS}, 0.01 \mathrm{M}, \mathrm{pH}$ $7.2,200 \mathrm{~g}$, at room temperature for $10 \mathrm{~min}$ and then adjusted to $10^{6} / \mathrm{ml}$ in Hanks' balanced salt solution and divided into $100-\mu \mathrm{l}$ aliquots per cytocentrifuge slide. Cytocentrifuge slides (Cytospin, Shandon Southern Instruments, Inc., Ft. Lee, $\mathrm{NJ}$ ) were air-dried and then fixed in ice-cold acid alcohol $\left(95 \mathrm{~cm}^{3}\right.$ methanol, $5 \mathrm{~cm}^{3}$ glacial acetic acid) for 30 min, then washed twice in ice-cold PBS, $0.01 \mathrm{M}, \mathrm{pH} 7.2$, for $30 \mathrm{~min}$. These slides were then stained in indirect and direct immunofluorescence.

Staining of plasma cells. $20 \mu \mathrm{l}$ of anti-RCRI antibodies at $150 \mu \mathrm{g} / \mathrm{ml}$ were added to the PWM-induced plasma cells on the cytocentrifuge slides for $30 \mathrm{~min}$ at room temperature, followed by a $30-\mathrm{min}$ wash in PBS, $0.01 \mathrm{M}$, pH 7.2. Sheep anti-rabbit immunoglobulin conjugated with fluorescein isothiocyanate was then applied to the same slide to stain RCRI-positive plasma cells as stated above. Sheep anti-rabbit immunoglobulin conjugated with fluorescein, when applied to slides not previously exposed to anti-RCRI antibodies gave no staining at all. The slides were again washed as before and finally, a goat anti-human immunoglobulin conjugated with tetraethyl rhodamine isothiocyanate was used to stain in direct immunofluorescence total plasma cells. Alternatively, goat anti-human mu and goat antihuman kappa conjugated with tetraethyl rhodamine isothiocyanate was used in direct immunofluorescence as a second stain.

Cohn Fraction II of human IgG (Miles Laboratories, Elkhart, IN) purified over DEAE $10 \mathrm{~mm} \mathrm{NaPB}$, pH 8.0, was conjugated with tetraethyl rhodamine isothiocyanate adjusted to $1 \mathrm{mg} / \mathrm{ml}$ and heat aggregated at $63^{\circ} \mathrm{C}$ for $10 \mathrm{~min}$ to prepare aggregates to counter stain RCRI-positive plasma cells in direct immunofluorescence. Fresh aggregates were prepared before each staining and spun at $9,000 \mathrm{~g}$ for $3 \mathrm{~min}$ at room temperature; the ability of each preparation to react with rheumatoid factor (RF) was checked by ring test in capillary tubes with monoclonal RF.

In vitro inhibition of idiotype production. Rheumatoid mononuclear cells adjusted to $1 \times 10^{6} / \mathrm{ml}$ in RPMI 1640 plus $20 \%$ FCS were incubated with PWM, as described above, and anti-RCRI antibodies at $10 \mu \mathrm{g} / \mathrm{ml}$ for $5 \mathrm{~d}$ at $37^{\circ} \mathrm{C}, 5 \%$ $\mathrm{CO}_{2}$ in air before harvesting. Resulting plasma cells were stained for total plasma cell and RCRI positive plasma cell numbers.

Synovial cell preparation. Synovial tissue was teased with forceps to liberate imbedded plasma cells. The resultant cell preparation was adjusted to $1 \times 10^{6}$ cells $/ \mathrm{ml}$ in Hanks' balanced salt solution before preparing cytocentrifuge slides.

Preparation of cryostat sections of peripheral blood PWM-induced plasma cells. Peripheral blood, PWM-induced plasma cells from patient Glo (member, Wa group), were pelleted at $200 \mathrm{~g}$ for $10 \mathrm{~min}$ at $4^{\circ} \mathrm{C}$. A $0.5-\mathrm{cm}^{3}$ layer of Ames O.C.T. compound (Miles Laboratories) was placed on top of the cell pellet and then frozen in a methanol, dry ice snap-freezing mixture. Frozen cells were kept at $-70^{\circ} \mathrm{C}$ until $4-\mu \mathrm{m}$ cryostat sections were made.

Cryostat sections were fixed in cold acetone for $10 \mathrm{~min}$

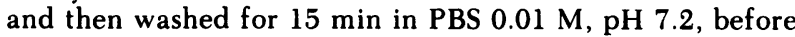
staining the cells in indirect and direct immunofluorescence.

Waaler-Rose hemagglutination assay for $R F$. Washed sheep erythrocytes were coupled with purified human IgG with glutaraldehyde as previously described (10). Aliquots of sera, $20 \mu \mathrm{l} /$ well, were titrated over 48 dilutions in PBS $0.01 \mathrm{M}, \mathrm{pH} 7.2$, with $1 \%$ absorbed FCS before human IgGcoated sheep erythrocytes were added.

Latex fixation by rheumatoid sera. Latex particles coated with purified human IgG (Hyland Laboratories, Costa Mesa, CA) as described previously (11) were used to measure RF titer of the various rheumatoid sera.

Monoclonal IgM reduction and alkylation. Reduction and alkylation of monoclonal IgM from patient Glo was performed as described previously (12). In short, IgM preparations were reduced by dialysis against $0.1 \mathrm{M}$ mercaptoethanol (Eastman Chemicals, Rochester, NY) in sodium phosphate, $\mathrm{pH} 7.5$ buffer, 0.2 tonic strength. Dialysis was allowed to proceed for $3 \mathrm{~h}$ at room temperature with stirring of the ethyl mercaptan solution. At the end of the dialysis period, the dissociated samples were either alkylated in order to prevent spontaneous reassociation or allowed to reassociate by removal of the ethyl mercaptan by dialysis. Alkylation was effected by dialysis against a large volume of 0.02 $M$ monoiodoacetamide ( $K$ and $K$ Laboratories, Plainview, NY) prepared in the pH 7.5 buffer. Dialysis was allowed to proceed for $4 \mathrm{~h}$ at room temperature with stirring of the iodoacetamide solution. The reduced and alkylated samples were finally dialyzed against $\mathrm{pH} 7.5$ phosphate buffer in the cold overnight.

\section{RESULTS}

Appearance of cells containing RCRI in PWMstimulated cultures of peripheral blood lymphocytes $(P B L)$ from rheumatoid arthritis (RA) patients. PBL from normal individuals or from patients with RA included very rare cells with intracytoplasmic immunoglobulin detectable by immunofluorescence. These cells were too rare to perform reliable studies of intracytoplasmic RCRI. 
On the other hand, cultivation for $5 \mathrm{~d}$ with PWM induced the well-known maturation of $B$ lymphocytes to plasma cells with intracytoplasmic immunoglobulins easily demonstrable by immunofluorescence. The frequency of these cells varied in our experiments from $5-19 \%$ of all cells (Table II); there was considerable variation among different individuals, but no significant difference between the rheumatoid and the control groups. The frequency of IgM-containing cells was measured in the cultures of two RA patients and was found to be 64.3 and 62.0 per 100 immunoglobulincontaining cells, a finding comparable to that of $\mathbf{5 7 . 2}$ and 55.3 detected in two controls.

A striking difference between RA patients and controls was found when examining the frequency, in 5d PWM cultures, of cells containing the RCRI. This was found (Table II) in 10.6-18\% of plasma cells in RA patients, a frequency more than fivefold higher than that of $1.5-2.8 \%$ found in cultures of normal individuals.

These data are supplemented and qualified by the following facts: (a) The final absorption of the anti-

TABLE II

Cytoplasmic Immunoglobulins and RCRI Detected in RA and Control Cells after $6 d$ Culture of PBL with PWM

\begin{tabular}{lcl}
\hline \multicolumn{1}{r}{ RA } & $\begin{array}{c}\text { Percentage plasma } \\
\text { cells of all cells }\end{array}$ & $\begin{array}{c}\text { Percentage RCRI cells } \\
\text { of all plasma cells } 1\end{array}$ \\
\hline E.F. & $8.0(5.4-10.4)$ & $11.2(7.7-13.9)$ \\
M.S. & $5.5(5.0-5.9)$ & $12.0(11.3-13.3)$ \\
E.C. & $12.0(10.0-14.0)$ & $13.9(13.8-14.0)$ \\
M.J. & $8.3(7.0-9.6)$ & $10.8(9.4-12.2)$ \\
J.J. & $10.4(8.6-12.2)$ & $18.0(16.0-20.0)$ \\
H.L. & 12.0 & 17.1 \\
B.B. & 10.6 & 7.9
\end{tabular}

Normal

$\begin{array}{lcl}\text { N.A. } & 13.3(9.7-18.7) & 1.5(0.0-3.0) \\ \text { V.B. } & 11.1(6.8-14.4) & 2.8(2.1-3.5) \\ \text { D.E. } & 18.0(17.0-19.0) & 1.9(1.6-2.2) \\ \text { L.K. } & 11.3(8.5-14.0) & 2.0(1.8-2.2) \\ \text { P.R. } & 9.0(8.5-9.5) & 2.5(2.0-3.0)\end{array}$

- Data indicate the percentage of cells showing cytoplasmic staining with fluorescent anti-human immunoglobulins (see Methods), as counted among 100 total cells identified by phase contrast. The data give the average of two separate experiments the actual figures of which are given in parentheses.

I Data indicate the percentage of cells showing RCRI stained with fluorescein conjugated anti-RCRI antibodies absorbed with $12 \%$ NHS as counted among 100 immunoglobulin-containing cells identified by staining with rhodamine-conjugated antitotal human immunoglobulin antibodies (see Methods). Average of two experiments, actual figures of each experiment in parentheses.

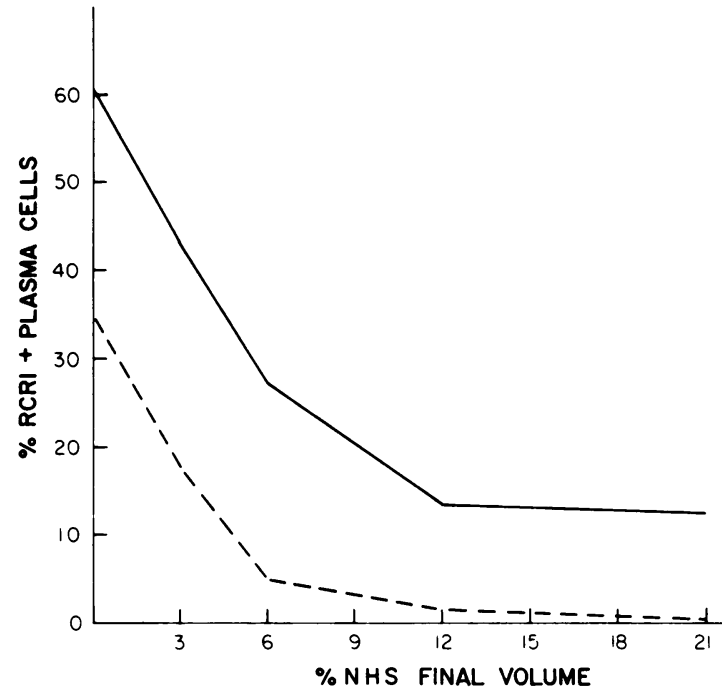

Figure 1 Effect of the final absorption with NHS of the anti-RCRI antibodies on the percentage of cells stained in 6-d PWM cultures from the PBL of a normal individual and a RA patient. Note plateau with absorption with $12 \%$ or more NHS._- RA; - - - normal.

RCRI antibodies with normal human serum influenced the percentage of cells stained with anti-RCRI antibodies (see Fig. 1). In RA cultures there was a decrease of the percentage of stained cells up to an addition of $12 \%$ (final concentration) normal human serum (NHS) to a solution containing $150 \mu \mathrm{g} / \mathrm{ml}$ of anti-RCRI.

A plateau was reached at $12 \%$ NHS concentration because further additions did not diminish the percentage of stained cells nor the brightness of the staining; in fact the intensity of the staining with absorbed anti-RCRI antibodies was quite comparable to that obtained on the same cells with anti-immunoglobulin antibodies (anti- $\mu$ antibodies) (Fig. 2a and 2b). (b) Since it was possible that the presence of immune complexes, expected on the basis of the absorption with fluid NHS, would affect the staining, absorption of the anti-RCRI antibodies was also performed with insolubilized polyclonal IgM instead of NHS. Parallel experiments showed no difference between the reactivity of antibodies absorbed with fluid NHS and those absorbed with solid IgM (data not shown). (c) In addition to the striking difference in frequencies of RCRI-positive cells, normal and RA cultures also showed a difference in the intensity of staining of the positive cells. This was distinctly lower in the normal cultures and appeared to be further diminished by absorption of the anti-RCRI antibodies with NHS concentration $>12 \%$. (d) The specificity of the immunofluorescent detection of intracytoplasmic RCRI was proven by the 

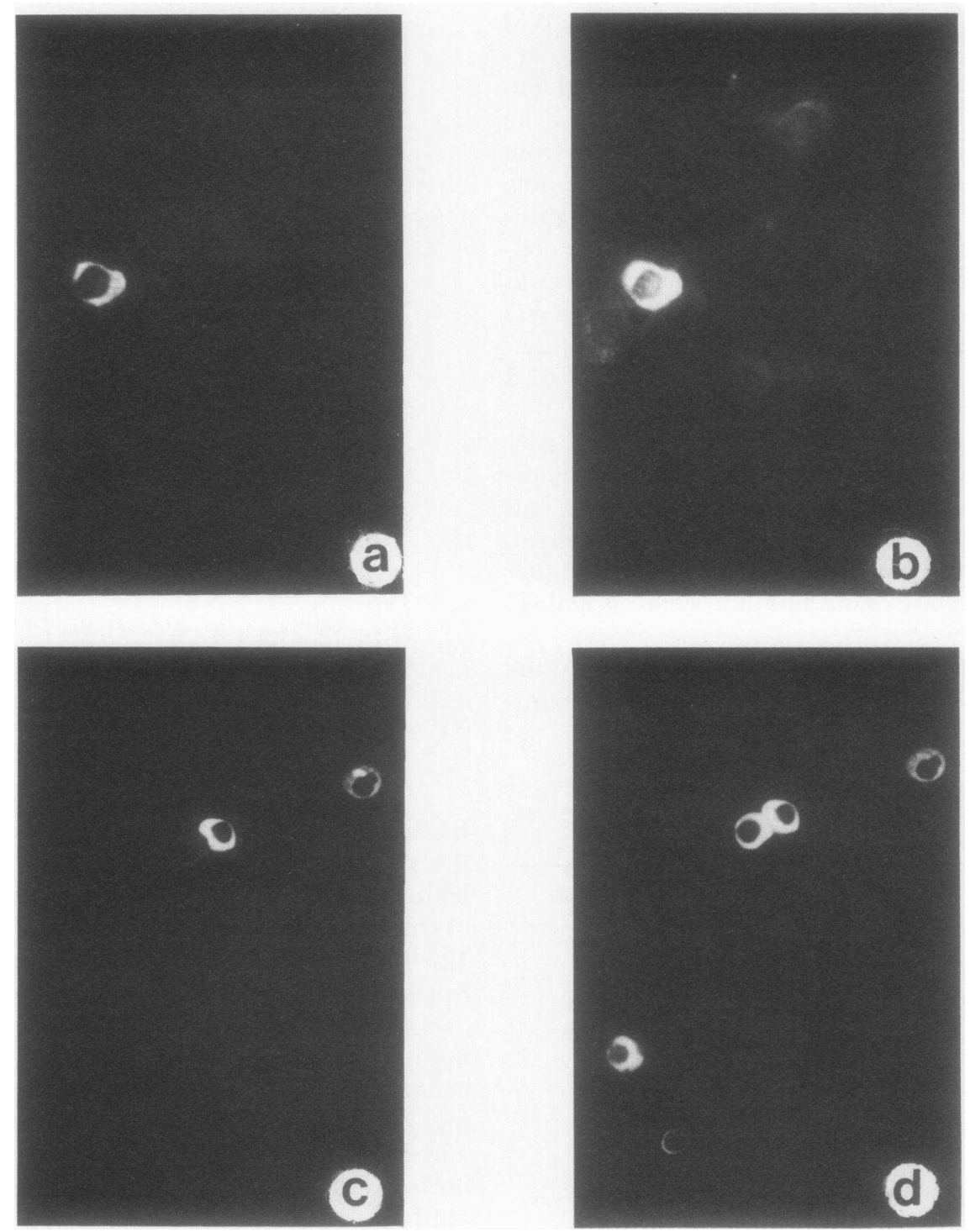

Figure 2 Immunofluorescence of plasma cells from 5-d PWM cultures from the PBL or from the synovial tissues of a RA patient. Staining with fluorescein conjugates for RCRI and rhodamine conjugates for IgM. All are at $\times 500$. (a) PWM cultures, selective illumination for fluorescein; one plasma cell shows the RCRI. (b) Same as A: selective illumination for rhodamine; the same cell also shows IgM. (c) Synovial cells, selective illumination for fluorescein; two plasma cells show RCRI. (d) Same as c: selective illumination for rhodamine; the same cells as $\mathrm{c}$ also show IgM. In addition, three other plasma cells are visible that have IgM but do not show RCRI.

fact that addition of $80 \mu \mathrm{g} / \mathrm{ml}$ of purified proteins Wa or Ea to a solution containing $150 \mu \mathrm{g} / \mathrm{ml}$ of anti-RCRI antibodies completely eliminated the staining. On the other hand, the addition of the same amount of normal polyclonal IgM or of monoclonal IgM without rheumatoid activity or even of rheumatoid monoclonal IgM with a different cross-reacting idiotype (protein Po) was without effect. (e) Double staining with anti-isotype antibodies showed that $>95 \%$ of the RCRI positive cells were IgM with $\kappa$-light chains, like their monoclonal prototypes. $(f)$ In contrast to the detection of rheumatoid cross-reacting idiotypes, we were unable to identify by immunofluorescence the antibody activity of rheumatoid factor in the cytoplasm of plasma 
cells induced by PWM culture of PBL from RA patients or patients with mixed cryoglobulinemia. In fact the classical immunofluorescence test for this activity, namely, the binding of fluorochrome-conjugated aggregated IgG, was negative in all our PWM cultures, including some cultures in which the presence of rheumatoid factor in the supernatant was detected by radioimmunoassay (13), and including the cultures from a RA patient that did show aggregate-binding plasma cells in the joints. $(g)$ The possibility that our inability to detect intracellular rheumatoid factors by aggregate binding was due to internalization of immune complexes bound in vivo by precursor lymphocytes, was considered unlikely because these internalized complexes would have been segregated in phagosomes and would not have mixed with the RF in the cisternae of the endoplasmic reticulum. Nevertheless, we performed an experiment with RBL of patient E.F. that were exposed to trypsin $(0.025 \%$ at room temperature, 5 min) before cultivation with PWM. Trypsin treatment did not affect the expression of the CRI in such culture, but did not change the negative result with the aggregate staining.

TABLE III

In Vitro Inhibition of Idiotype Production by Addition of Antiidiotype to PWM Cultures of PBL from RA Patients

\begin{tabular}{|c|c|c|c|c|}
\hline Patient & Culture contents & $\begin{array}{c}\text { Percentage } \\
\text { plasma cells } \\
\text { of total cells• }\end{array}$ & $\begin{array}{c}\text { Percentage RCRI }{ }^{+} \\
\text {cells of total } \\
\text { plasma cells } !\end{array}$ & Inhibition $\S$ \\
\hline \multirow[t]{3}{*}{ E.F. } & $\begin{array}{l}\text { PWM only } \\
\text { PWM }+10 \mu \mathrm{g}\end{array}$ & 5.4 & 13.8 & \\
\hline & $\begin{array}{l}\mathrm{RIgG} / \mathrm{ml} \\
\mathrm{PWM}+10 \mu \mathrm{g}\end{array}$ & 6.0 & 13.8 & 0 \\
\hline & $\mathrm{R} \alpha \mathrm{Id} / \mathrm{ml}$ & 5.4 & 2.1 & 84.8 \\
\hline \multirow[t]{4}{*}{ M.S. } & $\begin{array}{l}\text { PWM only } \\
\text { PWM }+10 \mu \mathrm{g}\end{array}$ & 5.0 & 12.2 & \\
\hline & $\begin{array}{l}\mathrm{RIgG} / \mathrm{ml} \\
\mathrm{PWM}+10 \mu \mathrm{g}\end{array}$ & 5.9 & 11.6 & 5.0 \\
\hline & $\begin{array}{l}\mathrm{R} \alpha \mathrm{Ia} / \mathrm{ml} \\
\mathrm{PWM}+10 \mu \mathrm{g}\end{array}$ & 4.2 & 4.3 & 64.8 \\
\hline & $\mathrm{R} \alpha \mathrm{TNP}$ & 5.6 & 11.7 & 4.0 \\
\hline
\end{tabular}

\footnotetext{
- Data indicate the percentage of cells showing cytoplasmic staining with fluorescent anti-human immunoglobulins (see Methods), as counted among 100 total cells identified by phase contrast. I Data indicate the percentage of cells showing RCRI stained with fluorescein conjugated anti-RCRI antibodies absorbed with $12 \%$ NHS as counted among 100 immunoglobulin-containing cells identified by staining with rhodamine-conjugated anti-total human immunoglobulin antibodies (see Methods).

\$ Percentage of reduction of cells containing RCRI in antiidiotype treated cultures, in comparison with control cultures.
}

Inhibition of the appearance of plasma cells with RCRI by the addition of anti-RCRI antibodies in vitro in PWM cultures of RA PBL. Small amounts (10 $\mu \mathrm{g} / \mathrm{ml}$ ) of anti-RCRI antibodies added to the culture medium at the beginning of the culture and present throughout the culture period, inhibited the appearance of cells with intracytoplasmic RCRI (Table III). The inhibition was quite specific since the anti-RCRI antibodies did not affect the maturation of plasma cells that did not contain the RCRI. Specificity was also indicated by the fact that normal rabbit IgG or rabbit anti-trinitrophenyl (TNP) antibodies did not have any effect.

Detection of the cross-reacting idiotype in the cytoplasm of PWM-stimulated cells from the blood of patients with monoclonal IgM cryoglobulinemia. Two patients with cryoglobulinemia of the mixed type in which the monoclonal IgM RF had the CRI of the Wa subgroup were available for study. Table IV reports the results of the intracytoplasmic fluorescent staining of the cells from 5-d PWM cultures of the PBL from these patients.

The lymphocytes of patient Glo generated more plasma cells than those of M.C. However, in both cases more than one-half of the immunoglobulin-containing cells reacted strongly with anti-RCRI antibodies. The intensity of the staining was, visually, comparable to that of the RCRI-positive plasma cells from the cultures of cells from RA patients; cells from patient Glo were stained with antibodies absorbed with fluid NHS or with solid IgM and as shown in Table IV, the results were comparable.

A striking finding with the cells of the PWM cultures from the blood of the cryoglobulinemia patients was the absence of binding of fluorochrome-conjugated aggregated IgG, just as was the case for the cultures from RA patients. There was no binding of the aggregates also when these were used alone; therefore the absence of binding was not due to blocking of the $\mathrm{RF}$ sites by the antiidiotype antibodies. It is noteworthy that the serum of the same patients gave a strong precipitin reaction with the same fluorescent IgG aggregates that failed to bind to the cytoplasm of the PWM-induced plasma cells, yet more than one-half of these cells were, by the idiotypic marker, identifiable as members of the RF-producing clone. ${ }^{2}$ The lack of staining with aggregated IgG did not appear to be due to problems with the penetration of the aggregated IgG in the cytoplasm of the ethanol-fixed plasma cells in the cytocentrifuge preparation, since there was also

\footnotetext{
2 This was confirmed, with a PWM culture of the PBM of patient Glo, by staining with antibodies for the individual idiotype.
} 
TABLE IV

Cytoplasmic Immunoglobulins and RCRI in Cells of PWMstimulated Cultures (Day 5) Derived from PBL of Two

Patients with Monoclonal IgM RF

(Members of Wa CRI Group)

\begin{tabular}{llccc}
\hline Patient & Cell preparation & $\begin{array}{c}\text { Percentage } \\
\text { plasma cells } \\
\text { of total cells }\end{array}$ & $\begin{array}{c}\text { Percentage RCRI } \\
\text { cells of total } \\
\text { plasma cellst }\end{array}$ & $\begin{array}{c}\text { Cells binding } \\
\text { aggregated IgG } \$\end{array}$ \\
\hline Glo & Cytocentrifuge & 23.2 & 68 & 0 \\
Glo & Cryostat section & 21.2 & 56 & 0 \\
Glo & Cytocentrifuge & 18.6 & 62 & 0 \\
M.C. & Cytocentrifuge & 7.6 & 50 & 0 \\
\hline
\end{tabular}

- Data indicate the percentage of cells showing cytoplasmic staining with fluorescent anti-human immunoglobulins (see Methods), as counted among 100 total cells identified by phase contrast.

I Data indicate the percentage of cells showing RCRI stained with fluorescein conjugated anti-RCRI antibodies absorbed with $12 \%$ NHS as counted among 100 immunoglobulin-containing cells identified by staining with rhodamine-conjugated anti-total human immunoglobulin antibodies (see Methods).

\& The anti-RCRI used for this staining was absorbed only with solid antigens (see Methods).

no aggregate binding by cryostat-cut cells from a pellet of the cells of patient Glo. The idiotype staining likewise gave the same results on the cryostat sections and on the cytocentrifuge preparations.

Staining with anti-RCRI antibodies and with fluorochrome-conjugated aggregated IgG of plasma cells from the synovial lesions of patients with RA. The results of double staining with anti-RCRI antibodies, followed by labeled aggregated IgG or antiimmunoglobulin of cytocentrifuge preparations of synovial cells from two patients with RA can be described as follows: (a) Aggregate binding plasma cells were found in these cell populations, at a difference from that observed in PWM cultures of the PBL of the same patients. The frequency of these cells was $6.0 \%$ of all immunoglobulin-containing cells in patient M.B. and $4.9 \%$ in patient H.L. (b) RCRI-positive plasma cells were also present (see Fig. 2); they were about three times more numerous than the aggregate-binding cells $(13.1 \%$ of all immunoglobulin-containing cells in patient M.B. and $14.6 \%$ in patient H.L.). (c) Onefourth to one-third of the RCRI-positive cells also bound aggregates $(22.7 \%$ in patient H.L. and $31.1 \%$ in patient M.B.). (d) Most, but not all, of the aggregatebinding cells showed the RCRI $(80.0 \%$ in patient H.L. and $77.5 \%$ in patient M.B.).

These data require some technical comments. First, it is clear that the penetration of aggregated IgG in the cytoplasm of ethanol-fixed cells can be obtained since the proportion of aggregate-binding cells in our cytocentrifuge preparation is not basically different from that reported by others (14) for cryostat-cut sections of active rheumatoid synovial lesions.

Secondly, the possibility that staining with antiRCRI antibodies was due to RF-containing cells reacting with immune complexes in the anti-RCRI preparation requires consideration. This possibility, negligible in the case of PWM-stimulated cells from the peripheral blood that showed no aggregate binding, arose again for the cells from the synovial tissues. However, the same results were obtained with anti-RCRI preparations treated only with solid absorbents and therefore presumably not containing immune complexes; in addition, there were definitely more idiotype positive than aggregate binding cells.

In the third place, the possibility of competition between the binding of aggregated IgG and that of anti-RCRI antibodies must be considered. In fact, this competition has been shown to occur in solution (15).

In this respect, the sequence of staining, with aggregates first, may have inhibited the binding of the anti-RCRI antibodies, but the reverse could not have happened. Actually, the antiidiotype staining of the cells that had bound the aggregates was often less intensive than that of the nonaggregate binding ones. However, the number of cells that stained with aggregates and not at all with the antiidiotype was low and certainly not higher than the one expected for RCRI-negative rheumatoid clones, indicating that probably aggregate binding did not completely block the antiidiotype binding in any cell; the possible reason for this is discussed later and may be due to the presence in the cytoplasm of some cells of an aliquot of molecules (IgM monomers) that do not form a stable bond with aggregated IgG, but still fully express the RCRI determinants.

\section{DISCUSSION}

The present observations indicate that the PBL of RA patients show a large number of plasma cells after PWM stimulation that bear the CRI previously demonstrated for many monoclonal RF. The number was much larger than for similarly stimulated cells from normal individuals and the intensity of fluorescent staining was considerably greater. It was evident that the degree of absorption of the cross-idiotypic antiserum was of special importance in a cellular study of this type. However, it was of interest that even under conditions of minimal absorption the contrast between the RA and normal plasma cells was obvious (Fig. 1). A plateau was reached with large absorptions with normal immunoglobulins where the contrast between RA patients and normals was striking but still a small 
percentage of normal cells showed the RCRI staining. The staining was specific; however, the intensity was definitely less than that of the cells from rheumatoid individuals or cryoglobulinemic patients. On this basis alone it remains unclear as to whether this is evidence for the presence of precursors of RF producers in the blood of normal individuals or if it merely indicates the presence in normal blood of clones with related idiotypes. A frequency of $\sim 1 \%$ of $\mathrm{B}$ cells reacting by immunofluorescence with antisera directed against the idiotypes of different human myeloma proteins has been reported by Kubagawa et al. (16). These wide cross-reactions have been defined previously as pseudoidiotypes (17) and must be considered in cross-idiotypic studies, especially when working with cellular immunofluorescence. However, Koopman and Schrohenloher (13) and Carson and associates (18) have recently detected the production of small amounts of RF in PWM cultures of PBL from 10 of 24 normal individuals; it is also known that significant $R F$ can be isolated from normal serum with aggregated IgG.

It was, of course, of interest to determine if these same PWM plasma cells from PBL of RA patients and normal controls stained for RF with aggregated $\gamma$ globulin. Surprisingly, all attempts to do this in these PWM cultures failed despite evidence for considerable RF production into the supernatant fluid of the PWM cultures of some of our RA patients (data not shown) in confirmation of previous findings $(13,18)$. Similar studies were carried out with the blood of cryoglobulinemia patients with high levels of monoclonal RF. Here, antiidiotypic antibody to the individual idiotype of this person's (Glo) RF was available that reacted specifically with RF in his serum. After PWM stimulation a very large percentage of his cells stained with this antiserum. However, again it was not possible to stain the cells with aggregated $\gamma$-globulin although the secreted RF reacted strongly with the antiserum. Cross-idiotypic staining of the cells of this patient also was obtained with considerably higher numbers of cells staining than in the RA cases.

Studies with synovial tissue from RA patients were then carried out in view of previous positive results for the staining of plasma cells in this locale with aggregated IgG. Indeed, positive results were obtained and the majority of the aggregate staining cells showed the CRI. However, additional cells were only positive for the CRI and not for aggregated IgG.

What is the explanation for the lack of binding of aggregated IgG by the immunoglobulins present in the cytoplasm of the PWM-stimulated cells? Considerable evidence indicates that the lack of aggregate binding was not due to lack of penetration of the IgG aggregates through the holes of the membranes of the fixed cells on cytocentrifuge slides. A study of the size of the molecules that penetrate such pores was done $e^{3,4}$ and showed that only molecules $>10^{6} \mathrm{~mol} \mathrm{wt}$ fail to bind to the intracytoplasmic immunoglobulins. Also, no binding of immune complexes of different sizes was found when, instead of aggregated human IgG, we used TNP-bovine serum albumin complexed with rabbit anti-TNP in a variety of antigen/antibody ratios. More cogent was the demonstration (Table III) that cryostat-cut sections of the PWM-stimulated cells of cryoglobulinemia patient Glo, where there should not have been a penetration problem, also showed no binding of IgG aggregates. Another possibility that one may consider is that a number of the idiotype-positive cells produced RF of the IgG class and that they failed to bind the IgG aggregates because of self-saturation of the binding sites (15). However, almost all the idiotype-positive cells (even in the joints) contained immunoglobulins of the IgM class; furthermore, the Wa cross-reacting idiotype has not been found in IgG RF. ${ }^{5}$

A reasonable interpretation for the existence of cells that synthesize RF and yet have intracytoplasmic immunoglobulins that fail to bind aggregated IgG, resides in the possibility that these cells, though secreting 19 $\mathrm{S}$, IgM, may have in their cytoplasm only IgM monomers that have a low binding affinity for IgG, but such monomers would react well in the cross-idiotypic and idiotypic systems. In the mouse, the majority of IgM synthesizing B cell clones contain very little intracellular immunoglobulin larger than $8 \mathrm{~S}(19,20$, 21). In human $19 \mathrm{~S} \mathrm{IgM} \mathrm{secreting} \mathrm{tumors,} \mathrm{the} \mathrm{pro-}$ portion of intracellular pentamer varied in different cases (22), but no data are available on PWM-stimulated cells that may be relatively immature plasma cells. It is known that these cells express Ia determinants and surface immunoglobulins that are absent from mature plasma cells (23).

We have found that the majority of these RF-containing cells react strongly with antibodies specific for the CRI of the monoclonal cryoglobulins of the major Wa group. This observation supports the concept that the polyclonal RF produced in RA are idiotypically related to the monoclonal $\mathrm{RF}$ observed in cryoglobulinemias of the mixed type. In this respect, the human RF system appears to be similar to other antibody systems in which immunoglobulins that react with the

\footnotetext{
${ }^{3}$ Tonda, P., and B. Pernis. Conditions for the demonstration of antigen binding by cytoplasmic immunofluorescence in plasma cell slides. Submitted for publication.

${ }^{4}$ Tonda, P., and B. Pernis. Sufficient affinity is necessary for intracellular immunofluorescence staining of antibodies. Antigens $>10^{5} \mathrm{~mol}$ wt do not penetrate the cytoplasm of fixed cells. Unpublished observation.

${ }^{5}$ Kunkel, H. G. Unpublished observations.
} 
same antigen molecules share CRI. Examples of this condition are the mouse anti-dextran (4) and anti-Ars systems (5) and the human cold agglutinin system (24). A particularly interesting analogy can be seen between the human rheumatoid system and the mouse antibodies directed against the $b$ allotype of the Ig2a class. In fact these anti-IgG antibodies have been shown (6) to have a CRI that is shared with monoclonal antibodies produced by hybridomas that react with different determinants of the same allotype.

It is therefore possible to understand the presence of common idiotypic determinants in the cryoglobulins of the Wa group and in plasma cells of rheumatoid lesions, that are presumably quite heterogeneous with regard to the specificity of the RF that they produce, corresponding to the different specificities found in rheumatoid sera (15). In addition to the cells that bound aggregated IgG and the antibodies directed against the CRI of the Wa cryoglobulin, the synovial tissue contained other aggregate-binding cells. These may have been producing $\mathrm{RF}$ idiotypically related to the other cross-idiotypic groups of cryoglobulins (25); we are currently investigating this possibility.

The process of maturation to RCRI-containing plasma cells could be inhibited in a specific fashion by the addition of small amounts of anti-RCRI antibodies to the cultures. This is clearly the consequence of an interaction of the antibodies with the membrane idiotypes of the precursor lymphocytes; it is similar to the suppression of other idiotypes in culture, by consequence of the addition of the corresponding antibodies, as reported by Mudawwar and by Bona and Fauci $(25,26)$.

A final remark concerns the immunofluorescence detection of RF. This procedure has been useful in the study of RA and has relied so far on the use of fluorochrome-conjugated aggregated IgG, introduced by Mellors in 1959 (27). However, it appears that this reagent detects extracellular RF (including those of germinal centers) that are pentameric molecules, but that it may fail to identify intracytoplasmic rheumatoid factors in many cells or clones of cells; certainly the aggregated IgG does not detect intracytoplasmic $\mathrm{RF}$ in plasma cells obtained by PWM cultures of PBL. It appears from the present work that the use of antibodies to the Idx of RF is of special value in cellular studies of RA, mixed cryoglobulinemia and related diseases. Monoclonal antibodies of this specificity would be particularly useful; our current efforts are directed at obtaining such reagents.

\section{ACKNOWLEDGMENTS}

The authors would like to thank Mr. Nicodemo Agostino for his expert technical help in the preparation of these experiments.
This research was supported by National Institutes of Health grants POI CA21112, RO1 Al 14398, and American Cancer Society grant M-191. Dr. Bonagura was supported by training grant A1-073202. Dr. Kunkel was supported by NIH grant AM 04761.

\section{REFERENCES}

1. Franklin, E. C., and B. Frangione. 1971. Common structural and antigenic properties of human $\gamma \mathrm{M}$ anti- $\gamma$ globulins. J. Immunol. 107: 1527-1534.

2. Kunkel, H. G., V. Angello, F. G. Joslin, R. J. Winchester, and J. D. Capra. 1973. Cross-idiotypic specificity among monoclonal IgM proteins with anti- $\gamma$-globulin activity. J. Exp. Med. 137: 331-342.

3. Forre, O., J. H. Dublong, T. E. Michaelsen, and J. B. Natvig. 1979. Evidence of similar idiotypic determinants on different rheumatoid factor populations. Scand. J. Immunol. 9: 281-289.

4. Schilling, J., B. Clevinger, J. M. Davie, and L. Hood. 1980. Amino acid sequence of homogeneous antibodies to dextran and DNA rearrangements in heavy chain $\mathrm{V}$ region gene segments. Nature (Lond.). 283: 35-40.

5. Nisonoff, A., P. Estess, E. Lamoyi, and J. D. Capra. 1980. Structural studies on induced antibodies with defined idiotypic specificities. J. Exp. Med. 151: 863-875.

6. Bona, C., P. K. A. Mongini, K. E. Stein, and W. E. Paul. 1980. Antiimmunoglobulin antibodies. I. Expression of cross-reactive idiotypes and $I r$ gene control of the response to $\operatorname{IgG}_{2 \mathrm{a}}$ of the b allotype. J. Exp. Med. 151: 13341348 .

7. Kunkel, H. G., R. J. Winchester, F. G. Joslin, and J. D. Capra. 1974. Similarities in the light chains of anti- $\gamma-$ globulins showing cross-idiotypic specificities. J. Exp. Med. 139: 128-136.

8. Ling, N. R., S. Bishop, and R. Jefferis. 1977. Use of antibody coated red cells for the sensitive detection of antigen and in rosette tests for cells bearing surface immunoglobulins. J. Immunol. Methods. 15: 279-289.

9. Lefkovits, I., and B. Pernis, editors. 1979. Immunological Methods. Academic Press, Inc., New York. p. 151.

10. Evans, J., M. Steel, and E. Arthur. 1974. A hemagglutination inhibition technique for detection of immunoglobulins in supernatants of human lymphoblastoid cell lines. Cell. 3: 153-158.

11. Singer, J. M., and C. M. Plotz. 1956. The latex fixation test. I. Application to the serologic diagnosis of rheumatoid arthritis. Am. J. Med. 21: 888-892.

12. Schrohenloher, R. E., H. G. Kunkel, and T. B. Tomasi. 1964. Activity of dissociated and reassociated $19 \mathrm{~S}$ anti-

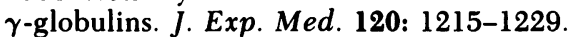

13. Koopman, W. J., and R. E. Schrohenloher. 1980. Enhanced in vitro synthesis of IgM rheumatoid factor in rheumatoid arthritis. Arthritis Rheum. 23: 985-992.

14. Munthe, E., and J. B. Natvig. 1972. Immunoglobulin classes, subclasses and complexes of IgG rheumatoid factor in rheumatoid plasma cells. Clin. Exp. Immunol. 12: 55-70.

15. Agnello, V., A. Arbetter, G. Ibznez De Kasep, R. Powell, E. M. Tan, and F. Joslin. 1980. Evidence for a subset of rheumatoid factors that cross-react with DNA-histone and have a distinct cross-idiotype. J. Exp. Med. 151: 1514-1527.

16. Kubagawa, H., L. B. Vogler, J. D. Capra, M. E. Conrad, A. R. Lawton, and M. D. Cooper. 1979. Studies on the clonal origin of multiple myeloma. Use of individually 
specific (idiotype) antibodies to trace the oncogenic event to its earliest point of expression in B cell differentiation. J. Exp. Med. 150: 792-807.

17. Kunkel, H. G., F. Joslin, and J. Hurley. 1976. Blocking of certain antigenic sites in the $F(a b)$ region by combination of univalent fragments of $\mathrm{Rh}$ antibodies with red cell antigens. J. Immunol. 116: 1532-1535.

18. Carson, D. A., J. L. Pasquali, C. D. Tsoukas, S. Fong, S. F. Slovin, S. K. Lawrance, L. Slaughter, and J. H. Vaughan. 1981. Physiology and pathology of rheumatoid factors. Springer Semin. Immunol. 4: 161-179.

19. Askonas, B. A., and R. M. E. Parkhouse. 1971. Assembly of immunoglobulin M. Biochem. J. 123: 629-634

20. Stott, D. I., and A. Feinstein. 1973. Biosynthesis and assembly of IgM free thiol groups present on the intracellular subunits. Eur. J. Immunol. 3: 229-235.

21. Buxbaum, J., and M. D. Scharff. 1973. The synthesis, assembly and secretion of gammaglobulin by mouse myeloma cells. J. Exp. Med. 138: 278-288.

22. Buxbaum, J., S. Zolla, M. D. Scharff, and E. C. Franklin. 1971. Synthesis and assembly of immunoglobulins by malignant human plasmacytes and lymphocytes. J. Exp. Med. 136: 1118-1130.

23. Halper, J., S. M. Fu, C. Y. Wang, R. Winchester, and H. G. Kunkel. 1978. Patterns of expression of human "Ia-like" antigens during the terminal stages of B cell development. J. Immunol. 120: 1480-1484.

24. Feizi, T., H. G. Kunkel, and D. Roelcke. 1974. Crossidiotypic specificity among cold agglutinins in relation to combining for blood group related antigens. Clin. Exp. Immunol. 18: 283-293.

25. Bona, C., and A. S. Fauci. 1980. In vitro idiotypic suppression of chronic lymphocytic leukemia lymphocytes secreting monoclonal immunoglobulin $M$ antisheep erythrocyte antibody. J. Clin. Invest. 65: 761-767.

26. Mudawwar, F., Z. Awdeh, K. Ault, and R. S. Geha. 1980. Regulation of monoclonal immunoglobulin $\mathrm{G}$ synthesis by anti-idiotypic antibody in a patient with hypogammaglobulinemia. J. Clin. Invest. 65: 1202-1209.

27. Mellors, R. C., R. Heimer, J. Corcos, and L. Korngold. 1960. Cellular origin of rheumatoid factor. J. Exp. Med. 110: 875-894. 